\title{
JEWISH FUNDAMENTALISM TODAY
}

\author{
Yehoshua Gitay \\ Old and New Testament \\ Stellenbosch University
}

\begin{abstract}
This paper asks the question: what is the meaning of Jewish Fundamentalism today? It tells the story of Jewish Fundamentalism as an exceptional phenomenon in current Jewish history which revolves around the matter of the Biblical idea of the Promised Land and it presents the matter of the Promised Land as a complex theological issue which splits Judaism when Fundamentalism is the dominant force. We are talking therefore about a peculiar Jewish Religious movement that strangely enough contradicts Orthodox Judaism; an unusual situation that requires elaboration. Furthermore, this paper makes a distinction between Orthodox Judaism and Fundamentalism. The paper claims that Jewish Fundamentalism contrasts the Jewish State, opposes its law, and actually maintains its autonomy as a powerful political force that is ready to reject the State's law regarding the issue of the Land.
\end{abstract}

Key words: Jewish Fundamentalism, Jewish Orthodoxy, Jewish State, Promised Land

\section{Jewish Orthodoxy: The Hermeneutical Principles}

Jewish fundamentalism today in Israel is the subject of this paper. The issue raises a number of key questions which revolves around the place and role of religious fundamentalism in the political milieu of modern Israel. Is it a unique religious phenomenon in the current history of Israel? What is the relationship between religious fundamentalism and Orthodox Judaism? Does Jewish fundamentalism contradict the laws of the Jewish state? Does it maintain only self-autonomy or the movement intends as well to gain a powerful political force that contradicts the State's laws regarding the political arrangements which revolves around the matter of the Land?

The present paper tells the story of Jewish Fundamentalism as an exceptional phenomenon in current Jewish history which revolves around the matter of the Biblical idea of the Promised Land. This paper presents the matter of the Promised Land as a complex theological issue which splits Judaism when Fundamentalism is the dominant force. We are talking therefore about a peculiar Jewish Religious movement that strangely enough contradicts Orthodox Judaism; an unusual situation that requires elaboration.

The matter of Jewish fundamentalism revolves around the central issue of Jewish Religion today which is the Land. Nevertheless, Judaism has developed a complex attitude towards the Land which involves various modes of movements when each of which reacts against the other regarding the matter. We are talking about Orthodox Judaism, the Zionist secular movement and Religious Zionism when the last movement has revised its attitude from real-pragmatism to a Messianic approach each of which interprets differently the idea of the Land. It appears that the question of the Land is not a mere theological meta-physical issue but a Religious issue which affects the current politics of the State of Israel when Religion and politics are inseparable.

Looking at the current debate we may conclude that the discussion is concerned with two major issues: (a) our understanding of the phenomenon of Religion versus Humanism 
and its application to the State's policy and (b) revealing the various principles of interpreting canonical texts in Judaism and applying the modes of interpretations to the political situation respectively.

Our first concern is with the matter of Religion versus Humanism. Thus, as we deal with the principles of Religion I want first to introduce Ernesto Grassi's definition which will lead the discussion. Grassi writes as follows:

as man's (sic) endeavor to construct a 'holy' intact cosmos which he (sic) conceives to be an overpowering reality other than himself (sic). This reality is that to which man (sic) turns in order to give himself (sic) a place in an absolutely meaningful order. This occurs through reassurance in the form of rites (1980:102).

Two words: religion versus secularism which represents two contradictory worlds when the non-real governs the real. Religion is the world of the absolute that does not admit the possibility of a rainbow of speculations given a variety of world views. Further, Religion rejects the possibility of establishing a fixed idea based on a concept which does not transcend the reality into the sphere of holiness. On the other side, secularism is the call for reason that Spinoza defined as "the principle of the free human being" (Yovel 2003: book 4:68).

As a matter of illustration I call attention to a specific argument about the Land that takes place today in Israel. I want to demonstrate the principle of reasoning in contrast to religious dogmatism. The voice of secularism is the voice of reasoning which seeks to exclude the Religious voice from the political arena under the assumption that it contradicts human reasoning which is the realm of politics. In other words, the premise of the secular approach is that dogmatic religious thinking is an obstacle for fruitful negotiations because Religion is meta-real when reason is the only means of communication regarding earthly controversial issues. In other words, only negotiators of the 'real world' are capable to reach a political agreement. Thus, for instance, Dani Rabinowitz, a senior journalist of the leading secular Israeli newspaper, Haaretz writes under the title: 'There is a Partner' that only a secular Palestinian peace movement of reason is the key for a political agreement between the two nations (Haaretz 14 November 2000). That is, the only applied principle of persuasion regarding peace negotiations is Spinoza's principle of the 'free human beings'.

In other words, the tension between Religion and Humanism is unavoidable. We are talking about one authoritarian position which does not emerge on the basis of empirical analysis of the situation but interprets religious texts given their meta-physical world view. It is expected therefore that such a position will confront these world views which present the human being in the centre and employs rationality and human experience as the criteria of establishing policies and ways of managing the world.

The act of applying the religious principles to the world of the believers is done through the interpretation of the sacred texts. In other words, the issue revolves around the question how the believers read the texts. It appears that Orthodox Judaism resists a literal reading. That is, Judaism has developed a literary approach to the Scriptures which intentionally rejects a literal reading but rereads the canonical books in light of the morality of classical Rabbinical teaching.

As a matter of fact, the canon within itself reveals a continuing tendency to rewrite or reinterpret the Scriptures. There is therefore a tension between texts and ideology when the text is adopted to ideology, and not vice versa. Thus, for instance, one notices an ideological-theological tension between two religious schools regarding the meaning of one of the most sacred institute in Judaism, that is, the Sabbath. A comparison between the two versions of the Ten Commandments: Ex 20:2-17 and Deut 5:6-21 reveals two editions which 
share together the notion of the Sabbath as a sacred day of resting. However, the two editions differ regarding their reasoning for keeping the Sabbath:

Remember the Sabbath day and keep it holy. Six day you shall labour and do all your

work. But the seventh day is a Sabbath to God your God;

You shall not do any work - you, your son or your daughter, your male or female slave, your livestock, or the alien resident in your towns. For in six days God made heaven and earth, the sea and all that is in them, but rested the seventh day therefore God blessed the Sabbath day and consecrated it (20:8-11).

The Sabbath is sacred because it symbolizes the creation thus it manifests a religious cosmological concept. However, the parallel version of Deut 5 motivates the seventh day differently:

Remember that you were a slave in the land of Egypt, and God brought you out from there with a mighty hand and an outstretched arm... (20:15).

The cosmological element has been replaced through an historical-national and social explanation for the day of rest.

Furthermore, there are ample examples for rewriting entire books inspired each of which through different ideologies. An outstanding illustration is the relationship between the books of Samuel and Chronicles. A specific school of David's historiography represented through Chronicles - has been dissatisfied regarding the Samuel's presentation of the Messianic king and consequently rewrote the David's account through the Chronic's perspective.

As a rule, the phenomenon of rewriting specific biblical books is a well known literary genre which characterizes as well the post canonical writings. Thus, for instance, HalpernAmuru (1994) has studied a central topic in Jewish Religion which is the sacred place. It appears that there have been dynamic religious movements which felt the need to rewrite their Books given their disagreement with the classical sources as, for example, the book of Genesis has been rewritten through the Hellenistic period in the form of the book of Jubilees or the Genesis Apocrypon of the Qumran community which rewrote Genesis.

In accordance, classical-Orthodox Judaism is actually a literary reading and reinterpretation of the Scriptures. As a matter of fact, the door is opened for numerous interpretations even on the basis of common sense because, as a rule, Jewish orthodoxy is not dogmatic but flexible (see Kasher 2004:135-165). That is to say the act of canonizing the Torah did not cease the process of rewriting and deconstructing and reinterpreting the 'origin'. Thus, the Law of the Torah has been reinterpreted through the Rabbinic literature such as the Mishna and the Gemara (the Talmud). The Talmud, for instance, called the Oral Law (versus the written), reworked the biblical law of talio:

eye for an eye, tooth for tooth, hand for hand, foot for foot, burn for burn, wound for wound, stripe for stripe (Ex 21:24, compare Lev 24:16-21, Deut 19:21).

The Talmud (Baba Kama 84:1) rejects the literal application of the talio introducing instead the principle of the substitute, that is, compensation (consult Kook 1988:234-235). The concept of Oral Law manifests therefore a substitute to a literal performance of the law of the Torah when the written law contradicts the moral Rabbinic principles. We may conclude that when a law, which traditionally has been given to Moses on Mount Sinai but may not correlate with the Rabbinic principles of morality and common sense, such a law might be a subject of Rabbinic modification. That is to say the principle of a literal reading of the Scriptures, which is the starting point of Fundamentalism, does not apply as selfevident to Orthodox Judaism. 
Gen 13 provides a remarkable illustration of a conflict between a literal interpretation and a literary application which is based on the principle of morality and common sense. Abram has moved to Canaan given God's call and the Promise of the Land (Gen 12:1-3). However, we read about a dispute on wells in the semi-desert of the Negev (the southern part of Canaan) between Abram and his nephew Lot. For the sake of peace Abram is ready to compromise and to move to another piece of land; however, the issue is that the Land is not his personal property but a subject of God's Promise, that is, Abram has a sacred rights and religious commitments to the Land given the Promise. Nevertheless, the objective of God's Promise does not hesitate to offer to his nephew to split the Promised Land between the two of them to settle down the conflict. That is to say Abram actually is ready to compromise on the matter of God's Promise when he listens to the voice of human reasoning even in a case that might contradict his obligation to God. In other words, the voice of reason and the search for peace is the dominant principle of Abram's behaviour.

The discussion so far has presented Jewish Orthodoxy as a moral sensitive Religion which might reveal flexibility regarding basic religious issues through a literary interpretation of the Scriptures. However, Fundamentalism differs because it presents a literal rather than literary - reading of the Scriptures with a specific aim to determine the political course in light of the Sacred Text (consult Lustick 1988). That is to say the ideology of Fundamentalism is based on a literal textual interpretation that applies the movement's ideology upon the sacred texts given the believer's belief that is inspired by God's revelation or have been canonized by Religious authorities such as Medieval Jewish commentators (see Naor 2001:22).

\section{Orthodox Judaism and the Land of Israel}

Given our review of the Orthodox hermeneutical principles, the immediate concern is to determine the place of the Land in accordance with the Jewish sources and their modes of interpretation. We read in the Rabbinic sources as follows:

Whoever dwells in the Land of Israel lives without sin.

Whoever walks four cubits in the Land of Israel is assured of a place in the world to come (Talmud Bavli. Ketubah. 111a).

Dwelling in the Land of Israel counterbalances all of the divine commandments (Sifre on Deuteronomy 12:29).

Our Rabbis taught: if the husband desires to go up but his wife refuses she must be compelled to go up [normally, the husband cannot enforce his wife to move to another country] and if she does not consent, she may be divorced without ketubah [marriage contract]. If she desires to go up and he refuses, he must be compelled to go up, and if he does not consent, he must divorce her and pay her ketubah (B Ketubah. 110a).

That is to say the Rabbinical sources reveal by all means a deep commitment to the land of Israel as the essence of Jewish life and the fulfillment of the Torah's commandments through living in the Land (for a comprehensive study of the issue see Shweid 1979).

However, Orthodox Judaism had a severe theological problem which revolved around the idea of the Diaspora. The orthodox approach regards the above sources as the ideal when the exile is the reality. That is the exile is God's punishment caused as a reaction to the people's misbehaviour. In accordance, the exile is a matter of God's determination consequently Orthodox Judaism has applied the hermeneutical principle of the literary reading concerning the idea of living in the Land. Rabbinic Orthodox Judaism has introduced therefore the concept of the 'three oaths'. The principles of the oaths appear already in the principal Jewish Religious codex, that is, the Babylonian Talmud. Thus, the 
Babylonian Talmud (Ktuvot 111) has established that (1) The people of Israel will not return back on their own to the land of Israel by their numbers and by force. (2) The people of Israel will not rebel against the nations and (3) in the Diaspora the nations will not oppress too hard the people of Israel. Our concern revolves around the first oath:

Actually, the oaths are a Rabbinic elaboration on Song of Songs 3:5:

I adjure you, $\mathrm{O}$ daughters of Jerusalem ... do not stir up or awaken love

Until it is ready!

The love between the Shulamit and her beloved one should not be enforced, but wait for the proper time. This call for patience is applied by the Rabbis to the tension between the love for Zion and its fulfillment through human means, i.e. the religious concept regards the Diaspora as God's act which will be resolved only by God Himself in the Messianic age without any human initiative (consult Ravitzky 2006:277-306). The Religious meaning is that the Jewish situation in the Diaspora is a religious condition rather than a political situation that is a subject of 'correction' as Zionism understood it. Jewish Orthodoxy maintains therefore that the exile is God's reaction to the people's sins. In other words, God exiled His people and only God given His act in history will gather them together in the Land. Consequently, the religious-Talmudic principle has ruled out against any sort of human political action on behalf of the establishment of a State in the holy-Land or even immigrating by numbers to the land of Israel.

\section{Secular Zionism and Religious Zionism}

Zionism is a humanistic transformation of Judaism. Zionism is essentially a national ideological-political secular movement that appeared on the political scene given the leadership of a secular Viennese Jew, Theodore Herzl (1860-1904). The movement's aim has been to restore the Jewish political life in the land of Israel which has been internationally recognized through the Balfour declaration of the British government towards the end of World War One. The British government officially acknowledged the Jewish right for a political home in its historical land granting therefore international recognition to Jewish political autonomy in Israel under the British mandate (for the movement and its ideological history see Hertzberg 1971).

Needless to say that the Secular political means of establishing a political home in the land of the Bible, the Promised Land, through an international secular declaration contradicts the position of Jewish Orthodoxy. Consequently, a sharp conflict has taken place between Jewish Zionism and Jewish orthodoxy. In other words, Jewish Orthodoxy as a meta-political movement has opposed by all means Zionism and declared the movement as an anti-Religious manifestation which contradicts God's act in history.

However, Jewish orthodoxy is not monolithic and is divided between ultra orthodoxy and liberal-neo-orthodoxy. The later movement - referred to as Religious-Zionism - has joined secular Zionism and fully participated in the establishment of the Jewish State. Nevertheless, as Orthodox Jews they could not ignore the Talmudic principle of the three oaths which prohibited the building of a state as a human political initiative. Thus, Religious Zionism had proposed a middle way that enabled the movement to take an active part in the Zionist political project. Hence, Religious Zionism regarded the political secular venue of the Zionist movement as a matter of emergency rather than a proclamation of the Messianic vision. In other words, given the physical oppression of the European Jewry in the course of the $19^{\text {th }}-20^{\text {th }}$ centuries the gathering of the Jewish people in the land of Israel has been introduced by Religious Zionism as a shelter rather than a religious-theological manifestation. Therefore, the gathering of the Jews in the land of Israel as merely a matter 
of emergency has temporarily delayed the Messianic idea regarding the principle of the gathering together in the Land. Consequently, such an interpretation of the idea of returning back to the Land enabled Religious Zionism to divorce the settlement in Israel from the prohibitions of the three oaths (consult Schwartz 1997).

\section{Jewish Fundamentalism and the Settlements}

Interestingly enough the question of Land for Peace is regarded differently than Abram's by present Jewish Fundamentalism. Actually the change in attitude is surprising because the Jewish Fundamentalist movement has transformed itself from the flexible earthly Religious Zionism party into a Messianic movement.

The point is that Jewish ultra-Orthodoxy has not changed its negative attitude towards the State of Israel and Zionism as well. But Religious Zionism has altered its original approach to the matter of Jewish settlements in Israel and the question of the State. The movement has developed in due course a Messianic theology regarding the Land, which integrates the Messianic idea with the Jewish settlement all over the Promised Land. The revised movement is inspired by the teaching of two Rabbis, a father and a son, Rabbi Avraham Kook, the first Chief Rabbi of Israel, under the British mandate (1865-1935) and his son and pupil, Zvi Yehudah (1891-1982), the head of a Yeshiva called merkaz Harav (the Rabbi's centre). In contrast to the ultra orthodox approach which distanced itself from the political sphere of the State as well as the settlement project - Rabbi Avraham Kook regarded the Land and its Jewish occupation as the essence of Judaism, its soul. He was inspired by the Medieval Jewish philosopher and Torah's commentator, Rabbi Moshe Ben Nahman (Ramban) (1194-1270) who regarded the life in the Land as a command. The Ramban expressed himself sharply and coherently:

We are ordered to inherent the Land that God gave to Abraham, Isaac and Jacob (1971).

And Rabbi Kook wrote as follows:

The land of Israel is the spiritual spring of the internal holy, which is the light of the soul of Israel (1963:134).

The land of Israel is not something apart from the soul of the Jewish people; it is not a mere national possession, serving as a means of unifying our people and buttressing its material, or even its spiritual, survival. Erez Israel is part of the very essence of our nationhood; it is bound organically to its very life and inner being. Human reason ... cannot begin to understand the unique holiness of Erez Israel; it cannot stir the depths of love for the land that are dormant within our people. What Erez Israel means to the Jew can be felt only through the Spirit of God which is in our people as a whole, through the spiritual cast of the Jewish soul... (1910:419-31).

In accordance, Rabbi Kook interpreted the Zionists secular movement as a pre-step towards the age of redemption. He understood the secular Zionist movement as a necessary development even though this movement in itself will not bring the Messianic age. Later on, claimed Rabbi Kook, the secular movement will integrate itself into the world of religious belief advancing therefore the course of redemption (consult Schwartz 1997:62-80).

Rabbi Kook developed therefore an independent theological approach regarding Zionism and the question of settling the Land: he differs from secular Zionism because for him the State is a tool but not the ultimate goal. He differs from Ultra-Orthodoxy because he believed in the Zionist pragmatic way and regarded the Zionist work as a means for redemption. He also argued against Religious Zionism which considered the settlement in Israel as merely a shelter with no Messianic expectation. 
Furthermore, Rabbi Kook's pupils challenged Zionism for being just a political movement and not beyond. Thus, asked in a form of a rhetorical question Rabbi Tau a distinguished student of Rabbi Kook:

What can we say to the people who return back to the land of Israel with no clear commitment, with no search for the sacredness of the Land and its spiritual dimension, but they are influenced by general ideas which are inspired by other national movements, and their return is considered as an historical process which is distanced from God's ideal intention? (cited in Schwartz 1997:115).

Zionism is a political movement which is integrated into the natural course of the world political history; however, Jewish settlement in the land of Israel, Rabbi Tau argues, is a spiritual matter which must be regarded as a sacred obligation.

In any event, the theological seeds for settling the Land have been planted but only partially because still significant parts of the Promised Land were not under the political sovereignty of the state of Israel given the 1948 War of Independence and the political order that followed the war.

Nevertheless, a dramatic turning point took place in the 'Seventh Days War' (June 1967) when as a result of the war Israel occupied new territories which included the west bank of the Jordan river or - given the Biblical geography - the land of Judea and Samaria. This is the land that Rabbis Kook and Tau could only dream about under the previous political circumstances, i.e. a new political territorial situation has been created when Israel has occupied territories which are in harmony with the biblical boundaries of the Promised Land.

Interestingly enough, the sacred territory of the west bank was out of the politicalpragmatic target of the modern Zionist settlement which reflected as well Israel's politicalterritorial sovereignty. Now the political situation has been changed and gradually pupils of Rabbis Kook established a Religious political movement called Gush Emunim, the block of Faithfulness, which sought to affect the political situation through earthly means of semiannexation, i.e. a massive Jewish settlement in Judea and Samaria. That is to say Gush Emunim did not confine itself to the spiritual realm but took a dynamic pragmatic-political approach to fulfill its religious-messianic inspiration. The goal was to settle in Judah and Samaria thus literally fulfilling the Promise to the Patriarchs through living in the entire Land under the new political situation. The idea is that there is a harmony between the Jewish population in the entire spectrum of the Promised Land and the appearance of the Messiah. Gush Emunim is therefore a Religious fundamentalist movement which seeks to reach its spiritual vision through political means as a literal translation of the biblical Promise. The result is that Religious Fundamentalism has a decisive impact on the current political Israeli sphere (consult Taub 2007).

In this context, mention should be given to the fact that secular Zionism, which represents the left-centre of the political arena of Israel, never felt itself obliged to occupy the entire Land of the Promise but took, ironically, as Abram, a realistic approach. The tension between Fundamentalism and political secular Zionism is therefore unavoidable.

That is to say the Israeli victory of the 1967 war created a new situation when central sacred places of worship of the Jewish people in particular East Jerusalem, the holy area of the Temple and specifically the Western Wall - which were disconnected from Israel after the War of Independence of 1948 - now happened to be under the control of Israel. The following speech of the then Chief Rabbi of the Israeli army delivered at the 'free' Wall demonstrates the spiritual feelings: 
The vision of all the generations has been fulfilled. The city of God, the Temple. And the Western Wall - the symbol of messianic redemption - were redeemed today. You have fulfilled today the sacred oath:

If I forget you, O Jerusalem,

Let my right hand wither!

Let my tongue cling to the roof of my mouth,

If I do not remember you.

If I do not set Jerusalem

Above my highest joy (Ps 137:5-6)...

Thus says God:

Keep your voice from weeping...

For there is a reward for your work...

They shall come back from the land of the enemy

Your children shall come back to their own country (Jer 16-17)

(cited in Naor 2001:44-45).

The fundamentalist principle of interpretation is at work: reciting Biblical verses and assigning to them a concrete political meaning as the proclamation of God's word through the voice of the authority, the Chief Rabbi. This is the essence of Jewish fundamentalism which translates the present situation into the Biblical verse providing therefore a theological meaning to the political situation.

\section{The Conflict: State versus Fundamentalism}

Rabbi Zvi Yehudah Kook, the spiritual leader of Messianic Zionism, spoke as follows on the idea of the sacred in the context of the Promised Land:

A sacred existence is not in our hands. God has determined that we are sacred people...

(cited in Taub 2007:52).

Rabbi Kook did not speak in meta-realistic terms; he called for concrete political acts which are not under human control but up to God. Messianic Religious Zionism has been transformed into the real word, i.e. a massive project of Jewish settlement in the Biblical area of Judah and Samaria. At this moment the movement has set itself in a deep conflict with the State's authorities.

As a matter of fact, the conflict between political realism - represented by secular reasoning in the format of the State - and the Religious authority has deep Biblical roots. Thus, the $8^{\text {th }}$ century BCE confrontation between king Ahaz of Judah and the prophet Isaiah may demonstrate the tension. Given the Assyrian invasion a coalition of the northern kings of Syria and Israel sought to stop the Assyria's military campaign. However, they needed Judah's support which was delayed given the hesitation in Jerusalem when her king struggled between a pro-Assyrian policy which would make him an Assyrian vassal but allowing him to keep his throne, on the one hand, or on the other hand, joining the antiAssyrian coalition which might save his political sovereignty as well as put all at risk, given the Assyrian's military strength. Ahaz's calculation was a matter of political reasoning. Meanwhile, the northern kings laid siege upon Jerusalem in order to force their antiAssyrian policy. At that dramatic moment the prophet voiced God's warning:

Then God said to Isaiah, go out to meet Ahaz ... and say to him: 
Take heed, be quiet, do not fear, and do not let your heart be faint because of these two smoldering stumps of firebrands [the kings of Syria and North Israel]...Thus says God: It shall not stand,

And it shall not come to pass...

Within sixty five years Ephraim will be shattered, no longer a people...

If you do not stay firm in faith,

You shall not stand at all (Isaiah 7:3-9; consult Gitay 1989:217-230).

Isaiah demands a policy of faith: 'believe and do nothing'; the believers must stay firm in their faith. Ahaz's dilemma was to listen to the prophet or to take a political stand which means to follow his own mind rather than the meta-political voice of belief.

That is to say pragmatism based on human reasoning versus Religious belief is the source of an unavoidable conflict which is the roots of the present tension between the fundamentalists and secular pragmatic policy in Israel. In other words, as far as the gulf between the ultra-orthodoxies and the fundamentalists, on the one hand, and the seculars, on the other, remains in the context of internal matters of Religious affairs, e.g., the question of keeping the law of the Sabbath which prohibits work or public transportation the conflict between the Torah's laws and the State's law might be a matter of negotiations. But when the conflict is revolved around the State's policy concerning the crucial matter of the Land then the tension involves the fundamentalists rather than the ultra-orthodoxies. In this regard, the gulf between the State's law and the Torah's is irresolvable (consult Gitay 2005).

The peace agreement between Egypt and Israel and the chain of political negotiations between Israel and the Palestinians made it clear that any political arrangement between Israel and its neighbours and the Palestinians in particular, would result in a territorial compromise on behalf of Israel under the formula of peace for territory. The application is that a major part of the Jewish settlements in Judea and Samaria or other parts of the Promised Land which are settled, as a rule, by members of the fundamentalist ReligiousZionist-Messianic movement may return back to the hands of the Palestinians. Indeed, there is a non-stop struggle which happened to be aggressive and physical that explodes when ever the State indicates her readiness for political negotiations with the Palestinians. Thus, the tension between State and Religious fundamentalism has been established when the fundamentalists settlers seek to dictate their commitment to the sacred Land either through political protests such as dramatic demonstrations against the secular government or by other means of brutal resistance.

The issue, in other words, is who is in control, which law is the dominant: The Torah or the State's? For Rabbi Goren at the time Israel's chief Rabbi - an official state's position the answer was obvious:

There is no law, national or international, which can change our rights to our forefathers' heritage regarding all the parts of our sacred Land. Thus, given the law of the Torah, the entire land of Israel is under our law (cited in Naor 2001:218).

In accordance, Rabbi Goren has concluded that:

a soldier in the Israeli army has the right to refuse an order which opposes the law of the Torah and should not obey the State's law (ibid, 218-219).

Thus, in a case of territorial withdrawal from the Promised Land every Jewish Israeli soldier has the right and, in fact, is obliged given the authority of the Chief Rabbi to obey only the law of the Torah. The Israeli soldiers are called therefore to disobey the army orders, that is, the State's law which is in light of the State's law a declaration of rebellion. 


\section{Conclusions}

Jewish fundamentalism is a political movement that literary translates the law of the Torah into the real world. Jewish Fundamentalism does not separate therefore between State and Synagogue and seeks to impose the Torah's law regarding the Promised Land upon the State.

The rise of Jewish Fundamentalism today is revolved around the idea of the Promised Land. Land in Judaism is not a mere geographical centre but a sacred idea. Actually, Judaism and Land are inseparable as the Biblical account of Abraham ties Judaism with the Land given Abraham's move to Canaan, the Promised Land. There he first sacrificed to God and only there God has revealed Himself to him (Gen 12:7).

Judaism has always regarded the Land as its soul. Indeed, the land of Israel is the subject of the Jewish prayer book. However, Orthodox Judaism regards the objective of building a Jewish home in the land as God's act in history which cannot be done through human initiative. Nevertheless, secular Zionism has related to the Land as a political means for the establishment of the State of Israel.

Fundamentalist Judaism has transformed the idea of the Land into Messianic theology and has translated the political situation of the post 'Six Day War' into political terms which are achieved through human initiative that, given the belief, is inspired by God and the sacred book of the Torah. Jewish Fundamentalism today is a real force which sets its theological dogma as its chief political target. The result is that Fundamentalism dictates, in fact, the political agenda of Israel creating a severe tension between State and Religion.

\section{BIBLIOGRAPHY}

Gitay, Y 1989. The Syro-Ephraimite War in Vermeylen, J (ed.). The Book of Isaiah. Louvain: Louvain University.

Gitay, Y 2005. The Religious Secular Dialogue in Israel. Haifa: Haifa University.

Grassi, E 1980. Rhetoric and Philosophy. University Park: The Pennsylvania State University.

Halpern-Amaru, B 1994. Rewriting the Bible. Valley Forge: Trinity Press.

Hertzberg, A 1971. The Zionist Idea. New York: Atheneym. Kook, A. אורות הקודש. דוד כהן) (ערן) (ערן) (עורך) י-ם: מוסד הרב קוק. תשכ"ג. עמ' קלד

Kasher, A 2004. Judaism and Idolatry. Tel-Aviv: Ministry of Defence (Hebrew).

Kook, A 1963. The Holy Ligh. (ed. Cohen, D). Jerusalem: Kook Institute (Hebrew).

Kook, A pp. 419-422 in Hertzberg, A (ed.) 1971. The Zionist Idea. New York: Atheneum.

Kook, YZ 1988. (ed. Aviner, Sh). The Talks of Rabbi Zvi Yehuda. Jerusalem: Meorei Or (Hebrew).

Lustick, I 1988. For the Land and the World. NY: Council on Foreign Relations=www.sas.upen.edu/penncip/lustick14.html (pp 1-10).

Moshe Ben Nahman 1971. The Rambam's Book of Commandments. Jerusalem: Kook Institution.

Naor, A 2001. Greater Israel: Theology and Policy. Haifa: Haifa University (Hebrew). Schwartz, D 1997. The Land of Israel in Religious Zionist Thought. Tel Aviv: Am Oved. Ravitzky, A 2006. Messianism, Zionism and Jewish Religious Radicalism. Tel Aviv: Am Oved (Hebrew).

Shweid, E 1979. Homeland and a Land of Promise. Tel Aviv: Am Oved (Hebrew). 
Taub, G 2007. The Settlers and the Struggle over the Meaning of Zionism. Tel Aviv: Miskal.

Yovel, Y 2003 (tr.). Spinoza’s Ethics. Tel Aviv: Hakibutz Hameuchad (Hebrew).

\section{For Further Reading:}

Aran, G 1991. Jewish Zionism Fundamentalism: The Block of the Faithful in Israel (Gush Emunim). pp. 265-344 in Marty, ME and Appleby, Rs (eds.).

Fundamentalism Observed. Chicago: Chicago University.

Armstrong, K 2000. The Battle for God. Hammersmith: Harper.

Encyclopedia of Fundamentalism 2001. Brasher, BE. NY: Routledge.

Peres, Y and Ben Refael, E 2006. Cleavages in Israeli Society. Tel Aviv: Am Oved (Hebrew).

Sprinzak, E Gush Emunim: The Iceberg Model of Political Extremism. Jerusalem Quarterly 21 $(1981)=$ www.geocites.com/alabasters_archive/gush_iceberg.html?200616 (pp 1-9). 